\title{
Pengaruh Kompetensi dan Independensi Auditor pada Kualitas Audit
}

\author{
Ni Ketut Ayu Mirah Pusparani ${ }^{1}$ \\ Fakultas Ekonomi dan Bisnis \\ Universitas Udayana, Indonesia \\ Email: Mirahpusparani97@gmail.com
}

\author{
I Dewa Nyoman Wiratmaja ${ }^{2}$ \\ Fakultas Ekonomi dan Bisnis \\ Universitas Udayana, Indonesia
}

\begin{abstract}
ABSTRAK
Akuntan publik bertanggungjawab profesional pada masyarakat atas kualitas laporan auditnya. Dalam melaksanakan tugasnya seorang auditor harus memiliki kecakapan dan pengalaman dengan mempertimbangkan kualitas dan kuantitas. Tujuan dilakukannya penelitian mengenai hubungan kompetensi dan indenpedensi pada kualitas audit adalah memperoleh bukti empris atas hubungan keduanya. Populasi dalam penelitian ini adalah 82 auditor. Teknik sampel jenuh merupakan teknik yang digunakan untuk menentukan sampel dan 52 auditor yang merupakan bagian 13 KAP yang terdaftar di IAPI dan dijadikan responden didalam penelitian ini. Analisis regresi linear berganda dipilih untuk menganalisis data. Hasil membuktikkan bahwa kompetensi auditor yang baik dan independensi yang bagus akan meningkatkankualitas laporan audityang dihasilkan seorang auditor.
\end{abstract}

Kata Kunci: Kompetensi, Independensi, Kualitas Audit.

\section{The Effect Of Auditor Competence And Independence On Audit Quality}

\section{ABSTRACT}

Publicaccountants are professionally accountable to the public for the quality of their audit reports. In carrying out its duties an auditor must have the skills and experience by considering quality and quantity. The purpose of conducting research on the relationship of competence and independence in audit quality is to obtain empirical evidence of the relationship between the two. The population in this study was 82 auditors. The saturated sample technique is a technique used to determine the sample and 52 auditors who are part of the 13 KAPs registered at IAPI and made respondents in this study. Multiple linear regression analysis was chosen to analyze the data. The results prove that good auditor competence and good independence will improve the quality of audit reports produced by an auditor.

Keywords: Competency; Independence; Audit Quality.

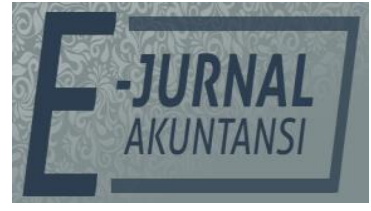

E-JA

e-Jurnal Akuntansi e-ISSN 2302-8556

Vol. 30 No. 3

Denpasar, Maret 2020

Hal. 725-732

Artikel Masuk: 5 Desember 2019

Tanggal Diterima: 17 Desember 2020 


\section{PENDAHULUAN}

Proses sistematis saat memperoleh bukti untuk dievaluasi dan dikaitkan dengan asersi-asersi perilaku seseorang dan hubungannya dengan kejadian ekonomi yang dinilai secara objektik dalam rangka menentukan tingkat kesesuai atas asersi yang ada merupakan bentuk proses audit. Hasil proses tersebut akan menentukan wajar atau tidaknya suatu laporan keuangan yang nantinya harus dikomunikasikan dengan pihak-pihak berkepentingan yang terkait dengan hasil laporan audit atas laporan keuangan tersebut (Mayasari, 2017).

Salah satu bentuk kemampuan auditor untuk dapat memproses hal terstukrtur agar bisa mengevaluasi bukti adalah bentuk kompetensi yang dimilki seorang auditor. Kemampuan, pengetahuan, keterampilan, perilaku kerja diserta atribut kepribadi seorang individu dalam hal berpikir kreatif, dalamnya ilmu pengetahuan, kemampuan kerja, kondisi kesehatan merupakan pengertian dasar kompetensi. Hal tersebut dapat dibuktikan seorang individu ketika melaksanakan tugas dan tanggung jawab yang merupakan beban kerjanya (Putri \& Rasmini, 2016).

Menurut De Angelo, (1981) ketika seorang auditor mampu menemukan ketidak sesuaian atau lebih jelasnya adalah suatu Prinsip Akuntansi bagi siapapun yang membuat laporan keuangan dan prinsip ini Berlaku Umum, mengenai susunan laporan auditeenya adalah takaran kualitas audit seorang auditor. Tidak menutup kemungkinan hal ini menjadi salah satu faktor dilematis bagi seorang auditor, dimana ada kalanya auditeenya memiliki kepentingan sendiri yang tidak jarang bertentangan dengan pihak-pihak yang berkepentingan atas hasil akhir laporan audit. Auditor dituntut untuk tidak fokus hanya pada kepentingan kliennya, akan tetapi lebih mengutamakan fokus hasil akhir laporan auditnya pada beberapa pihak yang membutuhkan atau pihak-pihak yang akan mempergunakan laporan yang telah diaudit. Informasi laporan keuangan akan lebih berkualitas apabila hasil audit atas laporan tersebut berkualitas dan pada akhirnya membantu pengguna untuk mengambil suatu keputusan dengan informasi relevan yang wajar sesuai dengan kondisi perusahaan sesungguhnya (Chanawongse, et al., 2011).

Selain kompetensi, independensi sang auditor merupakan satu faktor diantara sekian banyaknya faktor penunjang lainnya dalam menentukan kualitas audit seorang auditor. Auditor memiliki kode etik dalam melaksanakan kegiatan auditnya yaitu Standar Profesional Akuntani Publik (SPAP), apabila seorang auditor menjalankan langkah kerjanya berpedoman pada SPAP tentunya akan meningkatkan independensi auditor tersebut. Terdapat 6 pedoman dasar yang mengatur mengenai mutu profesional atau syarat dari pelaksanaan langkah kerja audit, pertimbangan tingkat materialitas yang akan digunakan dalam melaksanakan audit, pertimbangan ketika auditor akan menyusun laporan audit, serta optimalisasi auditor saat melaksanakan langkah kerja audit untuk macammacam bentuk sistem keuangan perusahaan. SPAP adalah pedoman yang dicetuskan oleh Ikatan Akuntan Publik Indonesia (IAPI) yang digunakan sebagai tolok ukur kualitas laporan audit dan diwajibkan bagi seluruh akuntan publik dalam memberikan jasanya (Gunawan, 2012). 
Pembaruan peraturan tentang tenure akuntan publik dan kantor akuntan publik dengan klien dicetuskan pemerintah untuk menghindari turunnya kompetensi yang dimilik auditor dan tingkat independensi auditor, misalkan dikarenakan faktor rentang audit tenure yang terlalu lama. Tidak sedikit perdebatan yang masih terjadi mengenai hubungan diantara tenure audit dan kualitas audit. Salah satunya yaitu penelitian Nasset, et al., (2006) yang menemukan bahwa semakin panjang masa perikatanaudit akan menurunkan independensi auditor karenamunculnya keterikatan secara emosional bagi pihak pemberi jasa yakni auditor dan pihak penerima jasa dalam hal ini auditee serta hal ini memberi pengaruh kepada auditor ketika harus mengeluarkan opini audit. Penelitian tersebut bertentangan dengan penelitian Cho \& Huang, (2012) menyampaikan mengenai ketidakjujuran didalam laporan keuangan lebih sering trjadi pada masa awal tenure audit.

Pada salah satu Kurikulum Inti Perguruan Tinggi yang berpedoman pada SK Mendiknas Nomor 045/U/2002 menjelaskan mengenai “Kompetensi adalah seperangkat tindakan cerdas, penuh tanggung jawab yang harus dimiliki oleh seseorang sebagai syarat untuk dianggap mampu oleh masyarakat dalam melakukan tugasnya di bidang tertentu". Imansari, et al., (2016) menambahkan keahlian dan kemampuan seseorang untuk menyelesaikan tanggung jawabnya merupakan salah satu pedoman pengertian kompetensi. Seorang auditor memiliki kewajiban dan tanggung jawab untuk menyelesaikan jasa auditnya, didasarkan pada penelitian sebelumya dan telah dikerjakan oleh Agusti \& Pertiwi, (2017) menyatakan suatu kompetensi auditor berdampak searah pada kualitas laporan audit yang dihasilkannya, semakin baik kompetensi sang auditor maka kualitas atas laporan audit yng dihasilkan oleh auditor juga semakin bagus. Maka $\mathrm{H}_{1}$ dalam penelitian ini adalah kompetensi berpengaruh positif pada kualitas audit.

Indepedensi seorang auditor merupakan kond isi seeorang auditor yang tidak memiliki ikatan dari adanya berpengaruh pihak lain. Seorang harus bersikap tidak memihak karena auditor bekerja demi kepentingan umum, semakin baik tingkat independensi seorang auditor maka kualitas laporan audit yang akan dihasilkannya juga akan semakin bagus. Penelitian mengenai hal ini pernah dilakukan Badjuri, (2011) diperoleh hasil bahwa independensi sang auditor berpengaruh positif/searah terhadap kualitas lapoan audit yang dihasilkan auditor yang bersangkutan. $\mathrm{Maka}_{2}$ didalam penelitian ini mengenai independensi auditor berpengaruh positif/searah terhadap kualitas audit.

\section{HASIL DAN PEMBAHASAN}

Auditor independen memiliki fungsi menilai laporan keuangan yang diterbitkan perusahaan apakah wajar atau tidak. Praktik sebagai akuntan publik haruslah mendapatkan izin dari Departemen Keuangan. Menurut SK MenKeu No. 424/KMK 06/2002 tertanggal 30 september 2002. KAP adalah suatu badan usaha dan badan usaha ini memiliki ijin langsung dari Menteri Keuangan, yang merupakan tempat untuk seorang auditor untuk mengeluarkan jasanya.

Instrumen penelitian yang digunakan adalah kuesioner dan objek penelitian yang dipakai untuk menjalankan penelitian ini adalah auditor pekerja di KAP serta trdaftar dan bisa diakses melalui direktori IAPI 2019 di Provinsi 
Bali. Penyebaran perangkat kuesioner ini mulai dilakukan pada tanggal 19 September 2019 dan kuesioner berhasil dikumpulkan kembalipada tanggal 25 Oktober 2019. Hanya 54 kuesioner yang bisa didistribusikan dan diterima oleh pihak kantor akuntan publik. Pada saat penyebaran kuesioner bertepatan dengan bulan audit, atau auditor yang bekerja pada KAP sedang melakukan pemeriksaan lapangan sehingga tidak ada ditempat, hal ini menyebabkan penyebaran kuesioner tidak dapat dilakukan maksimal. Selain kendala itu, ada dua KAP yng tidak dapat menerima kuesioner. Kedua KAP tersebut adalag KAP Ida Bagus Djagera dan KAP Sri Marmo Djogosarkono dan Rekan. Keduanya memiliki alasan yang berbeda, KAP Ida Bagus Djagera tidak dapat menerima kuesioner karena pemiliknya telah pensiun. Penolakan dari KAP Sri Marmo Djogosarkono dan Rekan karena sebagian besar auditornya sedang tidak ada di tempat atau sedang ada di lapangan. Keseluruhan kuesioner yang tersebar ada sebanyak 54 kuesioner, dan kuesioner yang dikembalikan sebanyak 52 kuesioner.

Uji asumsi klasik terfidiri dari (i) uji normalitas, (ii) uji heteroskedastisitas, (iii) uji multikolinearitas harus dilakukan terlebih dahulu untuk memastikan model penelitian laik untuk diregrsi. Model regresi yang baik diguanakan dan menghasilkan perhitungan data yang akurat apabila telah memenuji ketiga bagian uji asumsi klasik tersebut. Ketiga hasil pengujian disajikan pada Tabel 1. Yang merupakan rekapitulasi hasil uji asumsi klasik.

Tabel 1. Rekapitulasi Hasil Pengujian Asumsi Klasik

\begin{tabular}{llll}
\hline Variabel & Tolerance & VIF & Sig. \\
\hline Kompetensi $\left(\mathrm{X}_{1}\right)$ & 0,216 & 4,623 & 0,329 \\
Independensi $\left(\mathrm{X}_{2}\right)$ & 0,216 & 4,623 & 0,141 \\
Kolmogorov Smirnov-Z & 1,170 & & \\
Asymp.Sig (2 tailed) & 0,130 & & \\
\hline
\end{tabular}

Sumber: Data Penelitian, 2019.

Alasan variabel bebas harus lolos uji normalitas adalah untuk memastikan nilai residual dari model tersebut berdistribusi normal. Banyak cara untuk menilai normal atau tidaknya suatu data, namun pengujian dengan Kolmogorov-Smirnov dipilih untuk menguji kenormalan data yang dipakai di penelitian ini. Dapat dilihat dari Tabel 1. nilai kolomogorov-smirnov adalah 1,170 dan tingkat signifikansi 0,130 lebih besar dari $a=0,05$. Hal ini artinya bahwa data yang digunakan didalam penelitian ini berdistribusi normal.

Selanjutnya, setelah lolos pengujian normalitas, data yng dpakai didalam penelitian harus lolos uji multikolinearitas. Alasan dilakukan uji multikolinearitas dengan VIF dan tolerance untuk menilai perilaku data yang digunakan apakah data tersebut memiliki korelasi diantara variabel bebas yang dipakai. Data yang baik digunakan adalah data yang multikol atau tidak memiliki korelasi antar variabel bebas. Jika nilai VIF $<10$ atau tolerance $>10 \%$, maka dapat dkatakan model telah bebas dari multikolinearitas. Berdasarkan Tabel 1. nilai VIF kompetensi $\left(X_{1}\right)$ dan independensi $\left(X_{2}\right)$ sebesar 4,623 kurang dari 10 dan nilai tolerance untuk masing-masing variabel 0,216 lebih dari 10\% $(0,01)$ maka data tersebut dinyatakan lolos pengujian multikolinearitas.

Terakhir bagian uji asumsi klasik yang dilakukan adalah uji heteroskedastisitas yang memiliki tujuan memastikan data yang dipakai didalam 
penelitian tidak terjadi varians residual antar amatan. Uji Glejser merupakan pengujian umum yang digunakan untuk memastikan setiap variabel bebas yang diteliti tidak memiliki pengaruh signifikan pada nilai absolute residual. Peneliti dalam penelitian ini juga memilih uji tersebut untuk memastika bahwa data penelitian yang digunakan bersifat homos atau tidak mengandung gejala heteros. Pada tabel diatas yaitu Tabel 1. diperlihatkan nilai sig. dari variable kompetensi seorang auditor sebesar 0,329 dan independensinya auditor sebesar 0,141 . Nilai tersebut $>\alpha=0,05$ artinya tidak trdapat pengaruh antara variabel bebas trhadap absolute residual. Dengan demikian, nilai tersebut memastikan bahwa data yang digunakan tidak mengandung gejalas heteros. Uraian pada Tabel 1. hasil rekapitulasi uji asumsi klasik di atas menjadi dasar peneliti dapat menyatakan bahwa data yang digunakan lolos semua pengujian asumsi klasik sudah terpenuhi sehingga data yang digunakan laik untuk diteliti lebih lanjut dan dianalisis menggunakan regresi.

Regresi Linear Berganda merupakan teknik pengujian yang dipilih dan dipakai menguji pengaruh langsung variable independent (kompetensi dan independensi auditor) pada variabel dependent (kualitas audit). Hasil pengujian itu dilakukan melewati program SPSS dan hasilnya dapat dilihat pada Tabel 2. sebagai berikut:

Tabel 2. Hasil Regresi Linear Berganda

\begin{tabular}{|c|c|c|c|c|c|}
\hline Model & \multicolumn{2}{|c|}{$\begin{array}{l}\text { Unstandardized } \\
\text { Coefficients }\end{array}$} & $\begin{array}{l}\text { Standardized } \\
\text { Coeffiecients } \\
\text { Beta }\end{array}$ & $\mathrm{t}$ & Sig \\
\hline 1 (Constant) & 0,258 & 0,149 & & 1,731 & 0,090 \\
\hline Kompetensi & 0,487 & 0,104 & 0,499 & 4,694 & 0,000 \\
\hline Independensi & 0,448 & 0,102 & 0,467 & 4,391 & 0,000 \\
\hline Adj. R Square $\left(\mathrm{R}^{2}\right)$ & & 0,880 & & & \\
\hline F hitung & & 179,880 & & & \\
\hline Signifikan F & & 0,000 & & & \\
\hline
\end{tabular}

Sumber: Data Penelitian, 2019.

Pengujian SPPS dengan cara multiple regression analysis yang ditunjukkan hasilnya tertera pada Tabel 2 . diperoleh nilai koef. regresi setiap variabel bebas yaitu kompetensi seorang auditor dan independensi si auditor memiliki nilai signfikansi kurang dari $\alpha=0,05$. Hal ini artinya semua variabel independent memiliki pengaruh signifikant terhadap variable terikat dalam penelitian ini.

Hasil pengujian uji $\mathrm{F}$ memperlihatkan nilai $\mathrm{F}_{\text {hitung }}$ senilai 179,880 dan nilai signifikansi 0,000 lebih kecil dari $a=0,05$. Arti dari pernyataan tersebut adalah seluruh variable independent dalam penelitian ini mampu menjelaskan atau memprediksi fenomena pengaruhnya pada kualitas audit, untuk lebih tepatnya bhwa model regresi yang digunakan dalam penelitian ini adalah laik. Maknanya adalah seluruh variable indpendent yaitu kompetensi dan independensi mampu memprediksi atau menjelaskan fenomena kualitas audit. Hasil goodness of fit atas model yang dipakai didalam penelitian menunjukkan nilai baik karena nilai signikansinya adalah 0,000 artiya model yang digunakan dapat diproyeksikan atau dapat dianalisa lebih lanjut. Atau dapat dikatakan ada pengaruhnya antara kompetensi yang dimiliki auditor dan independensi si auditor pada kualitas laporan audit yang dihasilkannya. 
Didalam penelitian ini memakai nilai adjusted $R^{2}$ atau nilai koefisien diterminasi $\left(\mathrm{R}^{2}\right)$ yang disesuaikan dan ditunjukkan oleh Tabel 2. memperlihatkan nilai sebesar 0,880. Nilai ini memiliki arti bahwa fenomena mengenai kualitas laporan audit yang dihasilkan auditor dapat dijelaskan dengan variabel bebas yaitu kompetensi dan independensi sebeasar 88\%. 12 persen sisanya djelaskan oleh faktor lain yang tidak ada dalam model persamaan, atau variabel lainnya diluar model penelitian.

Dilihat dari hasil analisis pada Tabel 2. pengaruh kompetensi terhadap kualitas audit memperilihatkan nilai signifikasi sebesar 0,000 dan nilai koef. regresi positif sebesar 0,487 . Nilai sig. $0,000<$ dari $a=0,05$ artinya bahwa $\mathrm{H}_{0}$ ditolak dan $\mathrm{H}_{1}$ diterima. Hasil tersebut menjelaskan mengenai kondisi dimana smakin tinggi kompetensi seorang auditor maka semakin berkualitas laporan audit yang dikeluarkan auditor bersangkutan. Begitupula sebaliknya apabila kondisi yang terjadi adalah semakin rendah kompetensi yang dimiliki oleh seorang auditor, maka kualitas audit yang dihasilkan juga tidak bagus. Agusti \& Pertiwi, (2017) sebelumnya telah meneliti perilaku auditor di Bali dengan menggunakan variabel yang sama, dan hasil akhir penelitian ini menyetujui penelitian yang sudah pernah dilakukan oleh mereka, kedua hasil penelitian ini sama-sama memperoleh hasil bahwa kompetensi akan memberikan pengaruh positif terhadap kualitas audit. Norma tentang kompetensi wajib dimiliki oleh seorang auditor tercantum dalam (SA seksi 10 dalam SPAP 2011I, 2011) yang di dalamnya berisikan pernyataan bahwa, auditor saat melaksanakan audit memiliki kewajiban tentang keahlian dan pelatihan yang cukup dan mencakup ketelitian dan memiliki keahlian yang khusus. Hubungan positif diantara kompetensi dengan kualitas audit menunjukan bahwa, hasil peneltian memberikan bukti empiris mendukung pentingnya (SA seksi 210 dalam SPAP, 2011) yang memang dirancang oleh Kompartemen Akuntan Publik untuk menjamin laporan hasil audit yang berkualitas. Hal ini menunjukan tentang persyaratan peningkatan kualitas audit seorang auditor dituntut untuk meningkatkan pengetahuan mereka mengenai bidang yang ditekuninya, serta mampu menerepakan pengetahuan tersebut dengan baik. Pengetahuan ini diperoleh baik melalui pendidikan maupun pelatihan. Auditor dengan pengetahuan yang lebih baik akan lebih efisien dan efektif dalam menerapkan prosedur audit sehingga menghasilkan audit yang berkualitas tinggi. Memahami bahwa tingkat rentang kualitas audit (tinggi/rendah) ditentukan oleh kompetensi senantiasa meningkatkan kompetensi auditor melalui pendidikan dan pelatihan secara berkelanjutan.

Selanjutnya, berdasarkan pengujian analisis regresi atas pngaruh independensi terhadap kualitas laporan audit yang ditunjukkan pada Tabel 2. ditunjukkan nilai signifikansi sebesar $0,000<$ dari $\alpha=0,05$ dan nilai koefisien regresi positif sebesar 0,448 . Hasil yang ditunjukkan Tabel 2. memiliki arti bahwa smakin baik tingkat independesi yang dimiliki oleh si auditor sehingga kualitas laporan audit yang dihasilkannya akan menjadi lebih baik. Demikian pula sebaliknya, jika seorang auditor memliki tingkat independensi yang cukup rendah, kualitas laporan audit dihasilkannya juga akan berpengaruh terkadang kulitasnya menjadi tidak bagus. Auditor dengan suatu independensi yang baik merupakan auditor yang tidak terikat dengan adanya pengaruh pihak lain. 
Auditor harus memiliki sikap tidak memihak dan tidak terikat secara fisik maupun emosional, karena auditor bekerja demi kepentingan umum. Norma tentang independensi yang wajib dipunyai oleh seorang auditor termuat dalam (SA seksi 220 dalam SPAP, 2011) yang menyatakan didalam kesemua hal-hal mengenai hubungannya dengan tenure, maka independensi perilaku mental wajib untuk ditekankan oleh auditor. Hubungan searah antara independensi dengan kualitas laporan audit menunjukan bahwa hasil peneltian ini memberikan bukti empiris dan mendukung penerapan dalam (SA seksi 220 dalam SPAP, 2011). Standar Profesional Akuntan Publik (SPAP) lebih lanjut memberikan pedoman norma tentang kewajiban auditor untuk menggunakan standar umum keduanya (SA seksi 220 dalam SPAP, 2011) yang menyatakan pada setiap hal yang berhubungan dengan tenure, independensi perilaku mental harus dipertahankan oleh auditor. Seorang auditor yang mampu menjaga independensinya dipandang telah menjalankan kepatuhan terhadap (SA seksi 20 dalam SPAP, 2011) diharapkan mampu meningkatkan kualitas laporan audit.

Selain itu, hasil ini peneliti harapkan akan memberikan kontribusi mengenai informasi tambahan tentang pengaruh kompetensi yang dimiliki seorang auditor dan perilaku independensi audtior pada kualitas laporan audit yang dihasilkan. Hubungan positif antara variabel bebas (kompetensi dan independensi) dengan variabel terikat (kualitas audit) mendukung teori kepatuhan, dimana seorang auditor yang patuh terhadap (SA seksi 210 dalam SPAP, 2011)yang mengatur tentang kompetensi dan (SA seksi 220 dalam SPAP, 2011) yang mengatur tentang independensi menghasilkan audit yang lebih berkualitas.

\section{SIMPULAN}

Setelah dijelaskan mengenai hipotesis serta hasil pengujian sebelumnya, maka dapat disimpulkan dua hal penting. Pertama, kompetensi auditor berpengaruh positif/searah pada kualitas audit. Apabila auditor punya tingkat kompetensi yang baik dalam mengerjakan tugas-tugas audit dapat dipastikan kualitas laporan audit yang dihasilkan pastinya akan lebih baik. Dan kedua, Independensi auditor berpengaruh positif/searah pada kualitas audit. Demi memperoleh kualitas laporan audit yang maksimal auditor diwajibkan oleh pedoman SPAP agar memiliki tingkat independensi yang tinggi.

Di dalam penelitian yang dipaparkan beberapa beberapa bentuk saran dapat disampaikan oleh peneliti karena dirasa penelitian ini masih membutuhkan pengembangan konsep dan perbaikan, sehingga pada akhirnya akan bermanfaat bagi para peneliti lainnya. Saran sedrhana yang dipaparkan oleh peneliti pada beberapa pihak eksternal yang nantinya menggunakan penelitian ini sebagai acuran sebagai berikut: (1) Kepada Kantor Akuntan Publik (KAP) agar bisa menuntut auditor yang ada pada KAP bersangkutan meningkatkan kompetensi auditor melalui pendidikan berkelanjutan dan senantiasa menjaga sikap independensinya dalam melaksanakan tugas audit. (2) Berdasarkan hasil analisis regresi dalam penelitian diperoleh hasil perhitungan Adjusted $R^{2}$ senilai 0,880 menunjukan $88 \%$ variasi dalam hasil kualitas laporan audit dalam penelitian terpengaruh oleh variabel tingkat kompetensi yang dimiliki auditor dan perilaku independensi auditor, di lain sisi sebesar $12 \%$ 
dijelaskan oleh faktor lainnya diluar model penelitian, jadi peneliti menyarankan untuk para peneliti selanjutnya untuk dapat menguji variabe atau faktor lain selain kompetensi dan independensi auditor.

\section{REFERENSI}

Agusti, R., \& Pertiwi, N. P. (2017). Pengaruh Kompetensi, Independensi, Profesionalisme Terhadap Kualitas Audit. Jurnal Ekonomi, 21(3), 1-13. https://doi.org/10.22441/tekun.v8i1.5528

Badjuri, A. (2011). Faktor-Faktor Yang Berpengaruh Terhadap Kualitas Audit Auditor Independen Pada Kantor Akuntan Publik (Kap) Di Jawa Tengah. Dinamika Keuangan Dan Perbankan, 3(2), 183-197.

Chanawongse, K., Poonpol, P., \& Poonpool, N. (2011). The Effect of Auditor Professional On Audit Quality: An Empirical Study of Certified Public Accountants (CPAs) in Thailand. International Journal of Business Research, 11(3), 113-126. Retrieved from http://search.ebscohost.com/login.aspx?direct=true\&db=bth\&AN=7006582 6\&site $=$ ehost-live

Cho, V., \& Huang, X. (2012). Professional commitment, organizational commitment, and the intention to leave for professional advancement: An empirical study on IT professionals. Information Technology and People, 25(1), 31-54. https://doi.org/10.1108/09593841211204335

De Angelo, L. E. (1981). Auditor size and audit fees. Journal of Accounting and Economics, 3(5), 183-199.

Gunawan, L. D. (2012). Pengaruh Tingkat Independensi, Kompetensi, Obyektifitas, dan Integritas Auditor terhadap Kualitas Audit yang Dihasilkan Kantor Akuntan Publik di Surabaya. Jurnal Ilmiah Mahasiswa Akuntansi, 1(4), 44-48. Retrieved from http://journal.wima.ac.id/index.php/JIMA/article/view/245\%5Cnhttp:// jurnal.wima.ac.id/index.php/JIMA/article/view/245

IAPI. (2011). Standar Profesional Akuntan Publik. Jakarta. Retrieved from iapi.or.id/iapi/detail/362

Imansari, P. F., Halim, A., \& Wulandari, R. (2016). Pengaruh Kompetensi, Independensi, Pengalaman, dan Etika Auditor terhadap Kualitas Audit (Studi Empiris pada Kantor Akuntan Publik di Kota Malang). Jurnal Riset Mahasiswa Akuntansi Unikama, 4(1), 1-9.

Mayasari, D. (2017). Pengaruh Profesionalisme, Independensi, Kompetensi, Etika Profesi, dan Pengetahuan Auditor dalam Mendeteksi Kekeliruan terhadap Ketepatan Pemberian Opini Audit oleh Auditor. Skripsi. Sarjana Jurusan Akuntansi Fakultas Ekonomi dan Bisnis Universitas Islam Negeri Syarif Hidayatullah. https://doi.org/10.1017/CBO9781107415324.004

Nasset. (2006). Pengaruh Opini Audit, Distress, Financial terhadap Perusahaan Klien.

Putri, K. D. C., \& Rasmini, N. K. (2016). Fee Audit Sebagai Pemoderasi Pengaruh Auditor Switching Pada Kualitas Audit. E-Jurnal Akuntansi, 16(3), 20172043. 